\title{
The Determinants of Brazilian Football Clubs' Debt Ratios
}

\author{
Marke Geisy da Silva Dantas ${ }^{\dagger}$ \\ Universidade Federal do Rio Grande do Norte \\ Raimundo Marciano de Freitas Neto ${ }^{\Omega}$ \\ Universidade Federal do Rio Grande do Norte \\ Maria Alice Alves da Costa ${ }^{*}$ \\ Universidade Federal do Rio Grande do Norte \\ Alexandro Barbosa* \\ Universidade Federal do Rio Grande do Norte
}

\begin{abstract}
This paper explores the relationship between the debt ratio of Brazilian football clubs and several potential determinants, both financial and sports-related. Our explanatory variables are Current Ratio, Return on Assets, Score Percentage, Size, 12 Biggest Clubs, Access (to specific championships, e.g. Libertadores da América), Division, Title (won at time $t$ ) and Relegated (at time $t$ ). Data was collected from several publicly available channels and our sample was mostly decided according to this availability. The time range adopted was 2010-2013. The model employed was Generalized Estimating Equation. Our results suggest that debt ratios are more associated with their popularity or their participation in the highest division of its main championship rather than titles held, access to different competitions or relegation to lower levels. We believe that our findings may be useful for both practitioners, who might know the impact of their sports-related choices in their clubs' debts, and policymakers, that could prepare differentiated policies for specific groups (e.g divisions).
\end{abstract}

Keywords: Football clubs; Determinants; Debt Ratio; Profitability; First Division.

Received in 05/31/2016; revised in 06/24/2016; accepted in 09/11/2016; divulgued in 01/23/2017.

*Author for correspondence:

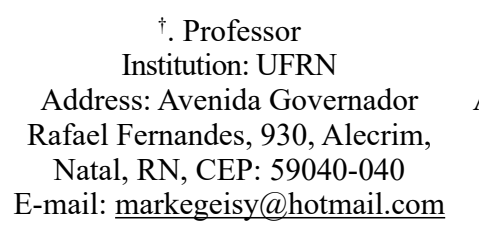

$\Omega$. Doutorando em Administração
Institution: UFRN

Address: Av. Senador Salgado Filho, 3000, Lagoa Nova, Natal, RN CEP 59078-970

E-mail: raimundomfn@gmail.com

\author{
*. Graduada \\ Institution: UFRN \\ Av. Senador Salgado Filho, 3000 \\ Lagoa Nova, Natal, RN \\ CEP 59078-970 \\ E-mail: alicecosta93@hotmail.com
}

\author{
*. Professor \\ Institution: UFRN \\ Av. Senador Salgado Filho, 3000, \\ Lagoa Nova, Natal, RN \\ CEP 59078-970 \\ E-mail: alexufrnet@gmail.com
}

Note from the Editor: The article was accepted by Bruno Felix. 


\section{INTRODUCTION}

$\mathrm{G}$ iven the financial difficulties football clubs are facing, studying their debt levels has become an important matter, considering its persistence over time. This issue is not limited to small clubs, as major clubs, and even national leagues or federations, are in a similar situation. (ANDREFF, 2007; BOSCÁ et al., 2008; BEECH; HORSMAN; MAGRAW, 2012). Finding a solution for this matter is a challenge yet to be professionally addressed by several clubs, and such procrastination may compromise their ability to survive (BEECH; HORSMAN; MAGRAW, 2012).

Beech, Horsmann and Magraw (2012) point out some reasons for the insolvency of English football clubs, like the absence of proper budgeting after relegation, fiscal debts, the change from soft to hard debts, and state that more financial specialists have come to manage those clubs, which may be a desirable trait.

The Union of European Football Associations (UEFA) imposed a financial fair play system to European clubs as an effort to improve their financial situation. Whilst Brazilian clubs may manage their finance at will, they are not financially performing as well as their European counterparts. Their managers, instead, seem to be more concerned with particular gains, such as visibility and political careers (BRANDÃO, 2012).

For Kuper and Szymanski (2010), football is neither a great nor a good business; it is likely that it should not even be considered a business at all. Gasparetto (2013) diverges and emphatically affirms that football is a great business, while Silva and Carvalho (2009) state the obvious paradox: in Brazil, a country world-widely renowned for its football, the football clubs are not able to properly manage their debts.

The lack of a strict legal environment seems to contribute for this deficit of professional management; nonetheless, some advances have been achieved, e.g. the promulgation of Lei Pelé (Law n. 9.615), which regulates several issues concerning sports, like doping controls; Law n. 10.672, which demands more accountability from sports clubs and Law n. 13.155, a statute concerning amateurish management, excessive expenditure and transparency issues. Silva and Carvalho (2009) presented evidence that clubs with better governance have better performance both in the football field and in their finance. These findings are aligned with Andreff (2007) and Dieltl and Frank (2007).

Football clubs may be viewed as firms, are looked up as potential business partners, with their main product shifting from the players to an entertaining on-field spectacle (LEONCINI; SILVA, 2005; NASCIMENTO et al., 2014), which is reinforced by their natural potential for product advertisement. There are yet some other particularities: people are actually rooting for them and its performance may be judged both on and off-field. For Rodrigues and Silva (2009), football 
has transformed from an organization founded in values and traditions into one that emphasizes efficiency, competitiveness and profitability, linking high investment and financial and sports performance (DANTAS, 2013).

For Dantas (2013), high investments may lead to wastes and to a more difficult financial situation, both in the short and in the long term. This reveals the fragility of the strategic planning developed by these organizations. BDO (2014) analyzed the financial reports and detected that the debt level of these clubs is a troubling and widespread problem - clubs of all sorts and sizes seem to have already been plagued by such financial disorder.

Several studies have tested the capital structure of conventional firms, searching for optimal debt levels, in contrast to the equity financing of operational activities (FAMÁ; PEROBELLI, 2002; WELCH, 2004; NAKAMURA et al, 2007). Brazilian football clubs have some particularities that must be taken into account, which includes their not-for-profit status, besides some specific variables that may be considered, such as field performance - translated into goal scoring and points earned in the championships and the actual conquering of a title. The notion that investments in infrastructure and player hiring may generate several liabilities translates into whether clubs who came out as champions are actually more indebted than others.

Some other studies related to finance and football clubs are focusing on efficiency, which is measured by a DEA-like method (e.g. GARCIA-SANCHEZ, 2007; DANTAS; MACHADO; MACEDO, 2015) or Corporate Governance issues (e.g. SILVA; CARVALHO, 2009; REZENDE; DALMACIO; SALGADO, 2010). Despite the indebtedness of Brazilian clubs being a sure fact, it has not been empirically investigated in former studies.

Our study has several points of convergence with Brandão (2012). First of all, our objectives are similar: whereas we study the determinants of debt ratio, Brandão (2012) tries to find causes for the high debt levels, focusing on financial and managerial variables. His evaluation is concerned with attributes like external auditors and fixed assets, whilst we direct our study towards sportsrelated characteristics, such as how well the team performed or the division in which it is currently playing.

Our actual research question is: what are the determinants of the total debt of Brazilian football clubs? As previously noted, even if their high debt level is troubling, empirical academic research about this subject is still scarce. To the best of our knowledge, only one dissertation (BRANDÃO, 2012) has studied the determinants of Brazilian football clubs' debts so far; whereas on a broader level, we have found the study of Mourão (2012), concerning Portuguese clubs.

\section{LITERATURE REVIEW}

Capital structure has been extensively studied and even if there are some classical papers (e.g. MODIGLIANI; MILLER, 1958) and further development (RAJAN; ZINGALES, 1995; FAMÁ; 
PEROBELLI, 2002; WELCH, 2004; BRITO; CORRAR; BATISTELA, 2007; NAKAMURA et al., 2007; FRANK; GOYAL, 2009; LONCAN; CALDEIRA, 2014), there is no consensus about the optimal capital structure. According to Brandão (2012), who analyzed a sample of 25 clubs and detected that only two of them were actual enterprises, all the others being not-for-profit organizations (NFPO), most Brazilian football clubs are NFPOs, and as such they are not concerned with investors' demands, their equity being mostly composed by retained surpluses from previous years.

Classical financial structure theories do not seem to apply in this setting, for the typical NFPO does not have any claims to its eventual profits, there are no tax benefits from any liabilities and there are no shareholders who may issue new shares to support the hiring of a new player. Unfortunately, it seems that the literature related to financing sources for NFPO's is underdeveloped.

Brazilian football clubs have long been suffering from quite high debt levels, as reported by Helal and Gordon (2002) and ratified by this paper - we report that some clubs had over 2,000\% more liabilities than assets to back them. Companies targeting increasing profits would likely be alarmed should these amounts be theirs, but for football NFPO's this seems not to be the case. Kuper and Szymanski (2010) report that this is one of the most stable sectors and that this lack of concern over such a serious matter comes from the absence of competition and competitive advantages, such as the obsolescence and changes in consumers' preferences, as it eventually occurs in other activities.

The studies concerning the determinants of football clubs' debts are sparse and mostly focused on European clubs, where it is typical for them to be created as profitable organizations, in opposition to the Brazilian scenario. Mourão (2012) suggested that the raise in Portuguese clubs' debt is mostly induced by lagged value of debt, players' wage, team's current classification and market area.

In a similar fashion, Brandão (2012) tried to identify what caused the massive levels of debt in Brazilian football clubs. He used three different dependent variables for his models: total debt; banking debt: loans taken from banks; banking and tax debts: the sum of loans taken from banks and several tax debts, such as taxes past expiration date. His main findings were that fixed assets, EBITDA, the Auditor Company and the expenses in raising new athletes are important to explain overall debts.

Garcia-Sanchez (2007) analyzed the economic behavior of the Spanish Football League separated in three aspects: operating efficiency, athletic (or operating) efficiency and social efficiency, which distinguishes the study from several others. Her main findings are different levels of efficiency between offence and defence and both related to poor management of the team. Dantas and Boente (2011) studied both the financial (revenues) and sports (score percentage) efficiencies 
of 20 European football clubs, creating an efficiency-based ranking and affirming DEA as a useful tool to assess the efficiency of these organizations.

Another efficiency study was developed by Halkos and Tzeremes (2012) - they analyzed European Football Clubs and found that those clubs' debt levels do not influence their efficiency levels. In opposition, Nascimento et al. (2015), who analyzed 13 Brazilian football clubs, found significant positive relationships between sports and financial efficiencies, financial efficiency and brand value, and the cost of the football department and the sports performance.

Dantas, Machado and Macedo (2015) evaluated the determinants of the efficiency of Brazilian football clubs, combining a super-efficiency DEA and a Tobit Regression, in which the DEAestimated efficiency was used as a dependent variable and Debt Ratio, Titles, Division, 12 Biggest Clubs, Access or Libertadores, Relegation, Scoring Percentage and Unsecured Liabilities. Their results suggested that only the variables Title and Division were significant variables to explain the clubs' efficiency.

Another commonly researched aspect of football clubs is Corporate Governance. Dimitropoulos (2013) analyzed the impact of corporate governance over the capital structure of a sample of 67 European football clubs, finding significance to shareholder-related variables. As most of Brazilian football clubs are not-for-profit, we do not expect to verify the same effect in our sample.

In the Brazilian scenario, Rezende, Dalmácio and Salgado (2010) analyzed a sample of 70 financial reports, from 2001 to 2007, from several football clubs, intending to detect impacts caused by legal enforcement mechanisms and found out that after their implementation the volume of published information effectively increased. Silva and Carvalho (2009) analyzed the financial reports from clubs that were in the first division of the Brazilian national championship in 2004 and concluded that better governance is associated with better performance.

The state of the art for academic literature on football clubs and their debts is still a story of many separated tales. There is yet no line of convergence between the researchers, as it seems that each one is looking for something completely apart from what has been done by the others.

Espitia-Escuer and García-Cebrián (2008) might be the ones closest to a proper summarizing of the current challenges a club must face in order to overcome such plaguing financial crisis. They advocate that football teams must take greater advantage of their resources - i.e. promote a more efficient use of their assets - along with the adoption of more aggressive strategies on the field of play, even if they are not presently facing some serious risk, as a relegation.

In this sense, they seem to be aligned to Leoncini and Silva (2005) and Nascimento et al. (2014), considering the football feature of an entertaining activity: more risk-taking strategies may be associated with more thrilling matches, and therefore with more satisfaction to their final 
consumer - the fan, which is likely to provide extra funds for the club in the long run, through sales of season-tickets, attendance at matches and advertising.

Exploring the gap in the literature concerning both the theoretical and empirical analysis of the indebtedness of Brazilian football clubs, our objective is a contribution to the empirical field through the study of the determinants of the debt level of these organizations.

\section{METHODS}

There are approximately 783 professional football clubs in Brazil (CBF, 2009), from which we selected a sample of 33 organizations, according to the availability of financial reports in their websites, newspapers or in official publications: ABC-RN, ASA-AL, Atlético-MG, AtléticoPR, Avaí, Bahia, Botafogo, Bragantino, Corinthians, Coritiba, Criciúma, Cruzeiro, Figueirense, Flamengo, Fluminense, Goiás, Grêmio, Guarani, Internacional, Joinville, Náutico, Palmeiras, Paraná, Ponte Preta, Portuguesa, Santa Cruz, Santo André, Santos, São Caetano, São Paulo, Sport, Vasco, Vitória. We collected yearly data, comprising the period of 2010 to 2013. The chosen variables are exhibited in Table 1.

The model employed for regressing the variables was Generalized Estimating Equation (GEE). Barbosa (2012) explained the GEE as a useful resource for cases when data is not normally distributed and they are time-correlated, which seemed to be the case for our data. We checked for normality using both Kolmogorov-Smirnov and Shapiro-Wilk tests, as displayed in Table 2, under the null hypothesis of normality.

We rejected the null hypothesis in both tests, indicating and ratifying the absence of normality. Therefore, we tested for a gamma distribution, a family of distributions that may also be used in modeling the GEE, as exposed in Table 3.

All tests were significant, suggesting that our dependent variable is gamma-distributed. The GEE may be used to test principal effects and interactions, evaluating continuous independent variables. This model accounts for the correlation structure between observations, producing efficient and unbiased estimates. The method employed for empirically choosing which correlation matrix should be used is the Quasi-likelihood under the Independence model Criterion (QIC).

\section{DISCUSSION}

Before discussing the data, it is important to note the relationship between the 12 Biggest and the First Division. The 12 Biggest clubs are fixed and they were selected according to the criteria proposed by Dantas, Machado and Macedo (2015), which involves mostly financial data. There is no factual link between both variables. It is possible that a club happens to be in both categories; 
Table 1. Regression Variables.

\begin{tabular}{|c|c|c|c|}
\hline Dependent Variables & Formula & References & Expected Sign \\
\hline Debt Ratio & $\begin{array}{l}\text { Short and Long Term Liabilities/ } \\
\text { Total Assets }\end{array}$ & Mourão (2012), Brandão (2012) & -- \\
\hline Independent Variables & Formula & References & Expected Sign \\
\hline Return on Assets (ROA) & Net Profit/Total Assets & Dantas (2013) & Negative \\
\hline Current Ratio & $\begin{array}{c}\text { Current Assets/Current } \\
\text { Liabilities }\end{array}$ & Nakamura et al. (2007) & Negative \\
\hline Cost/Asset & Operational Costs/Total Assets & Mourão (2012) & Positive \\
\hline Size & Ln of Net Operational Income & $\begin{array}{c}\text { Nakamura et. al. (2007), Famá e } \\
\text { Perobelli (2002) }\end{array}$ & Negative \\
\hline Score & Points Earned/Total Points & $\begin{array}{l}\text { Dantas, Machado and Macedo } \\
\text { (2015) }\end{array}$ & Positive/Negative \\
\hline Title (D) & $\begin{array}{l}1 \text { for the clubs that won a title } \\
\text { that year }\end{array}$ & $\begin{array}{l}\text { Dantas, Machado and Macedo } \\
\text { (2015) }\end{array}$ & Positive/Negative \\
\hline 12 Biggest (D) & $\begin{array}{c}1 \text { for the } 12 \text { Biggest Clubs (fixed } \\
\text { criteria) }\end{array}$ & $\begin{array}{l}\text { Dantas, Machado and Macedo } \\
\text { (2015) }\end{array}$ & Positive/Negative \\
\hline Relegated (D) & $\begin{array}{l}1 \text { for clubs that were relegated } \\
\text { that year }\end{array}$ & $\begin{array}{l}\text { Dantas, Machado and Macedo } \\
\text { (2015) }\end{array}$ & Positive/Negative \\
\hline Access (D) & $\begin{array}{l}1 \text { for clubs with access to } \\
\text { Libertadores da América } \\
\text { championship and/or were } \\
\text { promoted to a higher division } \\
\text { that year }\end{array}$ & $\begin{array}{l}\text { Dantas, Machado and Macedo } \\
\text { (2015) }\end{array}$ & Positive/Negative \\
\hline Division (D) & 1 for First Division Clubs & $\begin{array}{l}\text { Dantas, Machado and Macedo } \\
\text { (2015) }\end{array}$ & Positive/Negative \\
\hline
\end{tabular}

Table 2. Normality Test.

\begin{tabular}{lcccccc}
\hline \multicolumn{3}{c}{ Kolmogorov-Smirnov } & \multicolumn{3}{c}{ Shapiro-Wilk } \\
\hline & Statistic & $\mathrm{df}$ & Sig. & Statistic & $\mathrm{df}$ & Sig. \\
Debt Ratio & 0.232 & 132 & 0 & 0.538 & 132 & 0 \\
\hline
\end{tabular}

Source: Elaborated by the authors.

Table 3. Gamma distribution.

\begin{tabular}{lccc}
\hline Method & Value & Adj. Value & Likelihood \\
\hline Cramer-von Mises (W2) & 0.126089 & 0.126089 & {$[0.05,0.1)$} \\
Watson (U2) & 0.107384 & 0.107384 & {$[0.05,0.1)$} \\
Anderson-Darling (A2) & 0.760913 & 0.760913 & {$[0.05,0.1)$} \\
\hline
\end{tabular}

Source: Elaborated by the authors. 
in some cases we even expect them to. It is interesting to notice that none of the 12 Biggest escape the concept of NFPO.

Our results state that Debt Ratio is impacted by several financial and non-financial variables. We confirmed some of the initial expectations, such as a negative sign for ROA, Current Ratio and Size and a positive for Cost/Asset. We did not find enough support in other studies as to have a clear prediction as to what expect from our sports-related variables, but our results gave some important directions in this matter: Division and 12 biggest are positively associated to higher Debt Ratios.

\subsection{Descriptive Statistics}

Table 4 presents clubs' descriptive statistics in each year. The table has two sections, as not every descriptive is applicable to both continuous and binaries variables.

The variable Cost/Asset presents an increasing average and the ASA-AL club has presented the highest ratio for 3 of the 4 years pertaining our sample. ROA seems to suffer a decrease in its average from 2010 to 2011, but its behavior changes pattern in 2012 and then fall back in the following year. Its standard deviation is also irregular.

ASA-AL is the most profitable club in the years 2010 and 2012, whereas in the very same years Joinville showed up as the least one. There is no clear pattern for profitability in the other years. The mean current ratio faced an intense decline from 2010 to 2011 in both value and standard deviation. Even if there is an apparently extreme value behind this effect, the observation survived our outliers-excluding method and therefore was left in the sample. ASA-AL is once more well evaluated, having the most positive indicator over three years in a row. There are no matches between the lowest ROAs and lowest Current Ratios.

The logarithm of the income is growing over the years, even when its standard deviation takes a downward turn. The clubs with the highest income are not the same with the best ROAs, suggesting some lack of operational efficiency. The scoring percentage is directly associated to failure or success of the club: the one with the highest score is the winner of the championship as a whole.

The club that holds the least Debt Ratio for three consecutive years is Sport, a club that is not one of the 12 biggest. Our initial expectation about the relationship between this dummy and the dependent variable was unclear and this is the first empirical direction we obtain concerning this matter. Barueri, a club that had the highest Debt Ratio in 2011 and 2012, was in the First Division only in 2010. It would seem that either the relegation negatively impacted its income and made it hard to liquidate its debts or after the relegation the club began to make some major investments as an effort to go back to the First Division. 
Table 4. Descriptive Statistics.

\begin{tabular}{|c|c|c|c|c|c|}
\hline Variables & Statistic & 2010 & 2011 & 2012 & 2013 \\
\hline \multirow{4}{*}{ Debt Ratio (\%) } & Mean & 124 & 124 & 151 & 150 \\
\hline & Std. Dev. & 101 & 97 & 264 & 157 \\
\hline & Max. & 438 (Botafogo) & 1211 (Barueri) & 2072 (Barueri) & 675 (Bahia) \\
\hline & Min. & 22 (Paraná) & 17 (Sport) & 17 (Sport) & 15 (Sport) \\
\hline \multirow{4}{*}{ Cost/Asset (\%) } & Mean & 56 & 60 & 60 & 93 \\
\hline & Std. Dev. & 60 & 78 & 79 & 163 \\
\hline & Max. & 272 (Joinville) & 312 (ASA-AL) & 317 (ASA-AL) & 903 (ASA-AL) \\
\hline & Min. & 6 (Santa Cruz) & 10 (Náutico) & 7 (Santa Cruz) & 7 (Guarani) \\
\hline \multirow{4}{*}{ Score $(\%)$} & Mean & 54 & 53 & 53 & 50 \\
\hline & Std. Dev. & 8 & 8 & 9 & 10 \\
\hline & Max. & 68 (Coritiba) & 68 (Coritiba) & 70 (Goiás) & 73 (Cruzeiro) \\
\hline & Min. & 38 (Guarani) & 32 (Santo André) & 26 (G. Barueri) & 29 (Náutico) \\
\hline \multirow{4}{*}{ Current Ratio } & Mean & 3.46 & 0.45 & 0.63 & 0.34 \\
\hline & Std. Dev. & 15.81 & 0.63 & 1.37 & 0.42 \\
\hline & Max. & 90.36 (Figueir.) & 3.65 (ASA) & 7.99 (ASA) & 2.11 (ASA) \\
\hline & Min. & 0.02 (Náutico) & $0.00(\mathrm{ABC})$ & $0.00(\mathrm{ABC})$ & $0.00(\mathrm{ABC})$ \\
\hline \multirow{4}{*}{ Size } & Mean & 17.28 & 17.54 & 17.83 & 17.85 \\
\hline & Std. Dev. & 1.14 & 1.11 & 1.15 & 1.10 \\
\hline & Max. & 19.18 (Corint.) & 19.49 (Corint.) & 19.70 (Corint.) & 19.71 (S. Paulo) \\
\hline & Min. & 15.63 (S. Cruz) & 15.69 (Bragant.) & 15.63 (ASA) & 15.95 (ASA) \\
\hline \multicolumn{6}{|c|}{ Dummy Variables (Occurrence of values “1”) } \\
\hline Variables & Statistic & 2010 & 2011 & 2012 & 2013 \\
\hline Division & Frequency & 18 & 18 & 18 & 20 \\
\hline Title & Frequency & 11 & 12 & 12 & 13 \\
\hline 12 Biggest & Frequency & 12 & 12 & 12 & 12 \\
\hline Access & Frequency & 11 & 11 & 10 & 8 \\
\hline Relegated & Frequency & 4 & 2 & 5 & 5 \\
\hline
\end{tabular}

Source: Elaborated by the authors. Notes: Debt Ratio, Cost/Asset and Score Percentage must be read as percentages. Therefore, the first value of the table is $124 \%$. The names besides the values are the clubs to which those values correspond.

It is important to notice that for any given year, the mean of the Debt Ratios is higher than $100 \%$, expressing how alarming the situation is for the clubs in our sample: instantaneous conversion of all their assets into cash is not enough to liquidate their debts.

\subsection{Generalized Estimation Equations Modeling}

As discussed in the Method, there are four possible correlation matrices: independent; firstorder auto-regressive (AR1); unstructured - assumes that each observation inside the group has a different correlation value; and interchangeable - presumes that the correlation between observations inside a group is equal. The QIC statistics are displayed on Table 5. 
Table 5. Possible correlation matrices and their QICs.

\begin{tabular}{cc}
\hline Correlation Matrix & Debt Ratio's QIC \\
\hline Independent & 76.239 \\
AR(1) & 76.595 \\
Unstructured & 76.916 \\
Interchangeable & 76.607 \\
\hline
\end{tabular}

Source: Elaborated by the authors.

The lesser the QIC, the more efficient is the matrix. Thus, the Independent correlation matrix will be used. The main results are presented in Table 6 .

The current ratio is included to represent the ability the club has to liquidate short term debts; we expect that clubs with higher current ratios are not heavily dependent on debt, and thus the variables should be negatively related. By previously knowing how critical the situation of Brazilian football clubs is, we expect the Return on Assets to be negatively related to Debt Ratio: as a measure of profitability, we expect more profitable clubs to be better managed, not having extraordinarily high levels of debt.

As literature indicates that many clubs are poorly managed, we expect the ratio costs/assets to be positively related to Debt Ratio. Increases in costs not accompanied by proper decisions may make the situation even worse. The Cost/Asset ratio supports the hypothesis about the investment needs being included in the Debt Ratio, instead of being immediately liquidated. Moreover, as expected, the current ratio is negatively associated with Debt Ratio, suggesting that the higher the short term resources the club has to invest, the lesser are its needs to contract debt.

Size is a representation of the revenues earned in a period. We expect that more revenues may reduce the need for banking financing, since the club should be able to pay its immediate expenses. Our results support this statement.

A good score percentage may bring extra funds for the club: fans may feel more motivated to buy tickets for the matches and other products, like shirts and caps; therefore, it should be negatively associated. On the other hand, a team may need to compromise some of its budget in order to be able to win more matches and reach a better score percentage. If these expenses exceed the earnings, the club will need to rely on extra debt, increasing its Debt Ratio and thus, at least on short terms, the relation shall be positive.

Scoring also seems to be significant: the clubs that had the best scores accepted to have higher Debt Ratios, as they needed to invest more in their teams. However, variables concerning changes in their status, such as titles, relegations or obtaining access to popular championships, like Libertadores da América, do not seem to impact this ratio, considering that they were not significant. 
Table 6. Generalized Estimation Equations - Results.

\begin{tabular}{lccccccc}
\hline & Coefficient & Std. Error & $\mathrm{z}$ & & $\mathrm{P}>\mathrm{z}$ & & \multicolumn{2}{c}{$[95 \%$ Conf. Interval] } \\
\hline ROA & -0.958 & 0.450 & -2.130 & 0.033 & $* *$ & -1.839 & -0.076 \\
Current Ratio & -0.677 & 0.259 & -2.620 & 0.009 & $* * *$ & -1.184 & -0.170 \\
Cost/Asset & 0.663 & 0.195 & 3.400 & 0.001 & $* * *$ & 0.281 & 1.046 \\
Size & -28.324 & 10.250 & -2.760 & 0.006 & $* * *$ & -48.413 & -8.234 \\
Score & 1.702 & 0.476 & 3.580 & 0.000 & $* * *$ & 0.769 & 2.634 \\
Access & -1.774 & 10.106 & -0.180 & 0.861 & & -21.580 & 18.033 \\
Relegated & 16.567 & 14.349 & 1.150 & 0.248 & & -11.556 & 44.689 \\
Division & 34.929 & 16.987 & 2.060 & 0.040 & $* *$ & 1.635 & 68.223 \\
12 Biggest & 54.338 & 22.519 & 2.410 & 0.016 & $* *$ & 10.200 & 98.475 \\
Titles & -1.952 & 8.048 & -0.240 & 0.808 & & -17.725 & 13.821 \\
Constant & 441.993 & 177.837 & 2.490 & 0.013 & $* *$ & 93.440 & 790.547 \\
\hline
\end{tabular}

Source: Elaborated by the authors. Notes: Level of significance: $10 \%$ : *; 5\%: **; 1\%: ***. Observations: 129 . Wald chi2 $(10)=37.14 ;$ Prob $>$ chi2 $=0.0001$; Family: Gamma. Correlation: independent.

As an additional effect, more investments in infrastructure and better players may lead to winning a title. We expect this to cause a similar effect as we described for the score percentage. All these investments, however, could have had a low payoff and the club end up relegated, which may, in turn, lead to lesser incomes and maintenance or increase of the Debt Ratio in the following periods. Another reason for relegation may be the absence of hiring good players: the Debt Ratio may have reduced in that term, which would indicate a negative relation.

For the 12 Biggest and Division variables, we expect similar effects. The aforementioned clubs are favorites for the general public and are the ones who usually have the highest revenues and the most attention from the media. It is uncertain how much debt they are contracting as to maintain their status. On one hand, we may infer that their revenues are enough to keep their debt levels under low levels; on the other, their stead income may lead to a cycle of new contractions: the club expects that new hiring will reflect on more revenues, and thus more resources to liquidate both ongoing liabilities and the ones necessary to put this strategy into motion.

First division teams tend to spend more than other ones and their financing needs are also higher; likewise, the 12 Biggest tend to be part of the first division and have similar needs, even if they eventually get relegated to lower divisions in the championship. Actually winning a title in the period, losing the championship - and therefore getting relegated to a lower level class in the next term - and conquering the right to partake in another competition do not seem to impact the Debt Ratio.

Our results indicate that First Division teams and the 12 Biggest have higher Debt Ratios than the other ones, which may be related to higher wages paid to players and the fees that are part of contracting transactions and elevated general maintenance costs. This result seems to be aligned with the proposition of Mourão (2012) for Portuguese clubs. 
This puzzle does not apply to ROA: it is usual that first division clubs or the 12 biggest may have more infrastructure, such as owning a stadium or better training camps, and therefore higher total assets, but not necessarily higher profits, as this is highly dependent on the management decisions for that period.

The access variable indicates clubs that either got promoted to a higher division or conquered the right to participate in specific championships, such as Libertadores da América. This may have been motivated by new investments or be a reflex of past ones. The effort to be part of this group may reflect on a higher Debt Ratio - a positive relation. However, if the club ends up with more money, it may mitigate its need of external debt, reducing the Debt Ratio, and thus a negative relation.

This presents an interesting interaction with the Score variable, for it represents a condition to winning a title or progressing to higher levels in the championship, and the expected outcome - the actual conquering of the title - does not present itself as significant.

Overall, the financial variables are all converging: the better the profitability indicators, the lesser the ratio. ROA, and Size - as a representation of the net operational income - are both significant and negatively related to Debt Ratio, whereas the Cost/Asset has a positive relationship. The overall result is that the more profitable the club, the lesser is the Debt Ratio. This does not need to be directly translated into efficiency: a team with a humongous base of fans may periodically receive massive revenues and be sub-optimally spending it, without contracting any debt in the process.

Even if it makes sense from a purely financial point of view, it contrasts with the result of the sports variables: the First Division and the 12 Biggest clubs are likely to have the largest revenues and are positively associated to higher debts, whilst our representation of operational income suggests that their Debt Ratio should be lower. As stated by Dantas and Boente (2011), the sports performance is also a determinant for the income generating process, and thus these results should be aligned.

Our study have some points of convergence with Dantas, Machado and Macedo (2015), who generated an efficiency variable based on the output Score and inputs from operational revenues and expenses: our sample is a bit longer, but both studies have the same starting point: 2010; and we share a significant variable: Division.

Our empirical results imply that belonging to the First Division is associated with higher Debt Ratios. Dantas, Machado and Macedo (2015) rejected the relationship between Debt Ratios and their efficiency construct, yet they stated that First Division Clubs tend to be more efficient. It would seem that even if the efficiency does not cause or is caused by the Debt Ratio, it seems that one may be accompanied by the other.

\section{CONCLUSIONS}


Football can no longer be viewed as a mere sport, for now it must also be considered an entrepreneurship activity, an active part of our economy. Even if its objective is not, stricto sensu, the profit, a positive financial outcome is desirable, as to guarantee the maintenance of the organization in the long run.

These organizations have some peculiarities, such as the loyalty of their "customers". It is not often that a downgrade in the quality of players for a lapse of time will incur in a massive shift of teams - that is, even if the sports outcome clearly declines, we do not expect a great number of fans to adopt the banner of another team.

These characteristics assure some stability to football clubs, to the point that even with alarming high levels of debt, it is quite rare for them to actually declare bankruptcy. There is no real pressure on the management for efficiency in the expenditure of resources: steady income, no shareholders demanding for more accountability (and therefore very low or even zero agency costs), profitability is not an actual goal and there is no strong monitoring system.

Considering the atypical capital structure of these clubs, our study intended to evaluate the determinants of their Debt Ratio, a financial indicator essential to many firms, accounting for several sports variables, instead of the exclusive use of financial variables or ratios.

This study has some practical implications. The club may be perceiving immediate responses, that is, an increase in the debt which is promptly followed by a raise in income, which in turn may cause a reduction in the Debt Ratio - at least to a point where there will not be a statistically significant difference.

If debt is a main concern, a club should not focus in taking part of the first division; instead, it should try to strengthen its fan base and its income, and participating of different competitions may be a viable path, since it does not seem to impact the debt ratio. There also may be some overpricing, for the teams that are winning are not the ones who are expending the most. It may be the case of strong reinforcement from young players raised and trained by the club itself, which tends to be quite cheaper than hiring an experienced professional.

Brazilian government has recently issued Law n. 13.155, which focuses on the debts and management of these clubs. We believe that for policy-makers this research may also be taken in consideration, as we were concerned with the determinants of debt and this might be used for differentiated treatment for groups.

Our research has two important limitations: most sports variables used in the model were drawn from studies concerning football clubs' efficiency, instead of their debts, for our dependent variable is still lacking specific theoretical background; and few clubs actually make their financial reports publicly available, suggesting that the governance in this sector is still lacking. 
As previously noted, Law n. 10.672 imposes that clubs publicizes their financial reports; however, accountability does not seem to be an actual concern for these organizations, considering that many financial reports are not to be found in any of the databases that were checked, which include the typical official channels. Moreover, some of the reports do not follow the standardization proposed by the federal regulation (NBC T 10.13 and ITG 2003), which lead to unfavorable audit opinions.

Future studies may consider a broader sample of clubs or new variables. It seems important to address the puzzling matter as to why higher income seems to be related to a lower Debt Ratio, but a dummy which indicates clubs that are likely to have such incomes is associated to higher Debt Ratios.

\section{REFERENCES}

ANDREFF, W. French Football A Financial Crisis Rooted in Weak Governance. Journal of Sports Economics, v. 8, n. 6, p. 652-661, 2007.

BARBOSA, A. Pode a regulação econômica melhorar o desempenho econômico-financeiro e a universalização dos serviços de água e esgotos no Brasil? In: PRÊMIO SEAE, 7., 2012, Anais..., 2012.

BDO. $7^{\circ}$ Valor das marcas dos clubes brasileiros, 2014. Disponível em: <http://www.bdobrazil. com.br/pt/PDFs/Estudos_Zipados/valor_das_marcas_2014.pdf >. Acesso em: 20 Nov. 2015.

BEECH, J.; HORSMAN, S.; MAGRAW, J. Insolvency events among English football clubs. International Journal of Sports Marketing and Sponsorship, v. 11, n. 3, p. 53-66, 2010.

BOSCÁ, J.; LIERN, V.; MARTÍNEZ, A.; SALA, R. The Spanish football crisis. European Sport Management Quarterly, v. 8, n. 2, p. 165-177, 2008.

BRANDÃO, A. R. O endividamento dos clubes de futebol do Brasil. 2012. 170 f. Dissertação (Mestrado em Administração de Empresas) - Universidade Presbiteriana Mackenzie, São Paulo, 2012.

BRASIL. Lei n. 9.615, de 24 de março de 1998.

. Lei n. 10.672, de 15 de maio de 2003.

. Lei n. 13.155, de 4 de agosto de 2015.

BRITO, G. A. S.; CORRAR, L. J.; BATISTELLA, F. D. Fatores determinantes da estrutura de capital das maiores empresas que atuam no Brasil. Revista Contabilidade e Finanças, n. 43, p. 9-19, 2007.

DANTAS, M. G. S. Fatores determinantes da eficiência financeira e esportiva de clubes de futebol do Brasil. 2013. 96 f. Dissertação (Mestrado em Ciências Contábeis) - UNB e UFRN, João Pessoa e Natal, 2013.

; BOENTE, D. R. A eficiência financeira e esportiva dos maiores clubes de futebol europeus utilizando a análise envoltória de dados. Revista de Contabilidade e Organizações, v. 5, n. 13, p. 75-90, 2011. 
; MACHADO, M. A. V; MACEDO, M.A. S. Fatores determinantes da eficiência dos clubes de futebol do Brasil. Advances in Scientific and Applied Accounting, v. 8, n. 1, p. 113-132, 2015.

DIMITROPOULOS, P. Capital structure and corporate governance of football clubs. 2014. Management Research Review, v. 37, n. 7, p. 658-878, 2014.

DIETL, H. M.; FRANCK, E. Governance failure and financial crisis in German football. Journal of Sports Economics, v. 8, b. 6, p. 662-669, 2007.

ESPITIA-ESCUER, M.; GARCÍA-CEBRIÁN, L. I. Measuring the productivity of spanish first division football teams. European Sport Management Quarterly, v. 8, n. 3, p. 229-246, 2008.

FAMÁ, R.; PEROBELLI, F. F. C. Determinantes da estrutura de capital: aplicação a empresas de capital aberto brasileira. Revista de Administração - São Paulo v. 37, n. 3, p. 33-46, Jul./Set. 2002.

FRANK, M. Z.; GOYAL, V. K. Capital structure decisions: which factors are reliably important? Financial Management, v. 38, n. 1, p. 1-37, 2009.

GARCIA-SANCHÉZ, I. M. Efficiency and effectiveness of spanish football teams: a three-stage DEA approach. Central European Journal of Operations Research, v. 15, n. 1, p. 21-45, 2007.

GASPARETTO, T. M. O futebol como negócio: uma comparação financeira com outros segmentos. Revista Brasileira Ciências Esporte - Florianópolis, v. 35, n. 4, p. 825-845, Out./Dez. 2013.

HALKOS, G. E.; TZEREMES, N. G. A two stage double bootstrap DEA: the case of the top 25 european football clubs's efficiency levels. Managerial and decision economics, v. 34, n. 2, p. 108-115, 2013.

HELAL, R.; GORDON, C. A crise do futebol brasileiro: perspectivas para o século XXI. Revista do Programa de Pós-Graduação em Comunicação e Cultura da Escola de Comunicação da Universidade Federal do Rio de Janeiro, v. 5, n. 1, p. 37-55, 2002.

KUPER, S; SZYMANSKI, S. Footballnomics. 1. ed. Rio de Janeiro: Tinta Preta. 2010.

LEONCINI, M. P.; SILVA, M. T. Entendendo o futebol como um negócio: um estudo exploratório. Gestão e Produção, v. 12, n. 1, p. 11-23, 2005;

LONCAN, T. R.; CALDEIRA, J. F. Estrutura de Capital, Liquidez de caixa e Valor da Empresa: Estudo de Empresas Brasileiras Cotadas em Bolsa. Revista Contabilidade e Finanças, v. 25, n. 64, p. 46-59, 2014.

MODIGILIANI, F.; MILLER, M. The cost of capital, corporation finance and the theory of investment. The American Economic Review, v. XLVIII, n. 3, p. 261-297, 1958.

MOURÃO, P. The indebtedness of Portuguese football teams - looking for determinants. 2012. Journal of Sports Sciences - Braga/PT, v. 30, n. 10, p. 1025-1035, 2012.

NAKAMURA, W. T.; MARTIN, D. M. L.; FORTE, D.; CARVALHO FILHO, A. F.; COSTA, A. C. F. da; AMARAL, A. C. Determinantes de estrutura de capital no mercado brasileiro - análise de regressão com painel de dados no período 1999 - 2003. 2007. Revista Contabilidade e Finanças, v. 18. n. 44, p. 72-85, Maio/Ago. 2007.

NASCIMENTO, J. C. H. B. do; NOSSA, V.; BERNARDES, J. R.; SOUSA, W. D. A eficiência dos maiores clubes de futebol brasileiros: evidências de uma análise longitudinal no período de 2006 a 2011. Revista Contabilidade Vista \& Revista, v. 26, n. 2, p. 137-161, 2015. 
RAJAN, R. G.; ZINGALES, L. What do we know about capital structure? Some evidence from international data. Journal of Finance, v. 50, p. 1421-1460, 1995.

REZENDE, A. J.; DALMACIO, F. Z.; SALGADO, A. L. Nível de disclosure das atividades operacionais, econômicas e financeiras dos clubes brasileiros. Contabilidade, Gestão $e$ Governança, v. 13, n. 2, p. 36-50, 2010.

RODRIGUES, M. S.; SILVA, R. C. A estrutura empresarial nos clubes de futebol. Revista Organizações \& Sociedade, Salvador, v. 16, n. 48, jan/mar. 2009.

SILVA, J. A. F.; CARVALHO, F. A. A. Evidenciação e desempenho em organizações desportivas: um estudo empírico sobre clubes de futebol. RCO - Revista de Contabilidade e Organizações, v. 3, n. 6, p. 96-116, 2009.

WELCH, I. Capital Structure and Stock returns. The Journal of Political Economy, v. 112, n. 1, p. 106-131, 2004. 